\title{
Zero Degree Affects
}

O Grau Zero dos Afetos

MOYSES PINTO NETOa

CHARLES BORGES ${ }^{b}$

\begin{abstract}
This essay seeks a new approach between philosophy and neuroscience inspired by the recent ontological turn to think about one of the affects modulations across the contemporary sociopolitical scenario. In this regard, it theoretically triangulates the appropriation of Spinoza's philosophy by neuroscientist Antonio Damasio and the reception of Damasio's neuroscience by philosopher Catherine Malabou, taking Gilles Deleuze as a connecting point between these perspectives. It proposes to think the concept of destructive plasticity as a metamorphosis in the organism that, shocked by some traumatic event, turns to a new configuration that deactivates its somatic markers and ends up taking a form of disaffection. Finally, it concludes by bringing this figure closer to what Achille Mbembe, taking the death drive as central concept for thinking necropolitics, names as "lumpenradical".
\end{abstract}

Keywords: Affect. Plasticity. Destructive. Trauma. Disaffection.

\section{Resumo}

O ensaio busca uma reaproximação inspirada na recente virada ontológica entre filosofia e neurociências para pensar uma das modulações de afetos que atravessa parte do cenário sociopolítico contemporâneo. Para tanto, triangula teoricamente a apropriação da filosofia de Espinosa pelo neurocientista Antonio Damasio e a recepção da neurociência de Damasio pela filósofa Catherine Malabou, tomando Gilles Deleuze como um ponto de conexão entre essas perspectivas. Propõe pensar o conceito de plasticidade destrutiva como uma metamorfose de um organismo que, chocado com algum acontecimento traumático, reveste-se de uma nova

\footnotetext{
a Universidade Luterana do Brasil, Canoas, RS, Brasil. Doutor em Filosofia, e-mail: moysespintoneto@gmail.com

b Pesquisador independente, Porto Alegre, RS, Brasil. Doutor em Filosofia, e-mail: charlesdittgen@gmail.com
} 
configuração que desativa seus marcadores somáticos e acaba tomando uma forma de desafetação. Conclui aproximando essa figura do que o Achille Mbembe, partindo da pulsão de morte como conceito central para pensar a necropolítica, nomeia como o "lumpenradical".

Palavras-chave: Afeto. Plasticidade. Destrutiva. Trauma. Desafetação.

\section{Introduction}

After a long hegemony in the twentieth century second half of linguistic turn in philosophy and the human and social sciences, with its division of labor regime between philosophy and science demarcated by the separation between transcendental and empirical $^{1}$, recent resurgence of materialism and realism within what has been named "ontological turn" or "speculative turn"2 causes a structural change in the configuration of these relationships. Frankly opposed, for example, to the association between poststructuralist philosophies (especially in Deleuze and Derrida) and anti-realism, generally adopted under the arc of "postmodernism", thinkers associated with ontological turn seek to reconnect fields, postulating — in various forms — a reconstruction of the lost links with science.

In this sense, one of the bridges that reconstruction aims is the link between philosophy and biology. In general, under the Kantian and/or Heideggerian theoretical umbrella and much inspired by Michel Foucault's idea of biopolitics, contemporary "Continental" philosophy shows a certain aversion to reintroducing — after the eugenic and extremist experience of the twentieth century — biology as a problematizing element to notions such as consciousness, will, freedom and human (MALABOU, 2015). In general, under the resistance of humanistic variations - assumed or not —, idea of human transcendence against any biological description, or more specifically human consciousness irreducible to neurophysiological aspects, remains frankly hegemonic in the philosophical

\footnotetext{
${ }^{1}$ Forms in which this division was constituted are innumerable, from strong versions of transcendental to mitigated into immanent forms, such as that common to Habermas and Apel, of a transcendental linguistic-pragmatic intersubjective. In any case, what these theories have in common is their a priori postulation of experience which is constituted as their condition of possibility in Kant's tracks, and the twentieth century is the period in which he "lands" in thus becomes intersubjective (eg, APEL, 1980). ${ }^{2}$ For a general notion about "ontological turn", see Bryant et al (2011). Exemplifying these associations, see works of Richard Rorty (2002) and Lee Braver (2007). On the other hand, approaching Deleuze and realism, see for example the works of Protevi (2010), DeLanda (2002). In Derrida's case, see for example Hägglung (2008), Kirby (2009), Vitale (2018).
} 
environment. Reductionism ubiquitous claim is, in this light, verse and mastercard of transcendence.

Catherine Malabou is one of the philosophers who, in the arc of "new materialism", seeks to counteract this philosophical impulse, even naming it - with psychoanalytic inspiration — as the "philosophical resistance to neurobiology". In contrast to the vulgate that simply labels neuroscience infiltration as determinism, which she classifies as a "sclerotic tradition" (MALABOU, 2011, p. 26, free translation ${ }^{3}$ ), brain is thought as a "network of flexible and changing connections, where configurations and development escape in part from genetic determinism and where form is proper to each individual" (idem, p. 7-8). In her work there is an insistence against the philosophical tendency to oppose the symbolic to the organic (corporeal or material), finding a transcendence that would allow to surpass the biological. Her tendency, on the contrary, is to gather what has been separated: "the death of the symbolic is precisely what invites us to think of plasticity as impossible to make the division between biological life and spiritual life. There is only one life" (idem, p. 33, our translation). It is not a question, therefore, of wanting a transcendence, another messianic world, but understanding biological subjectivity and "acting on connections, modifying synaptic efficacy, otherwise circulating energy, changing power relations" (idem, p. 33).

The resumption of affections, therefore, involves partial abandonment of purely linguistic and rationalist paradigm of intersubjective relations to allow emotions and affections to reentry as structuring elements of these interactions between bodies. To this regard, concept or motor scheme that will lead us on this itinerary will be plasticity - the "federating" concept of neurosciences (MALABOU, 2011, p. 41). In this paper, after presenting theoretical framework that explores plasticity since Spinoza, Deleuze and Malabou, we aim to build a hypothesis based on the assumption of a balancing affect theory between philosophy and neurobiology (Damasio) that leads to destructive plasticity, understood as the zero degree of affections, looking for an instrument to think about necropolitical scenario in which we are inserted.

\footnotetext{
${ }^{3}$ We took the original because English translation does not have preface of second (French) edition.
} 


\title{
2. Conatus, metastability and affects
}

Our goal here is thinking about the concept of plasticity as conatus. We translate the concept of conatus as a tendency, that is, the vectors occupying a vectorial field in a complex and metastable system.

Complex systems tend towards certain attractors to form an interior opened to an exteriority; they are external to themselves insofar as exteriority exists only as it exchanges information to the system's interiority.

Thus, this tendency (conatus) doesn't match to any type of identity (or individual). Conatus is always a process of individuation. The individual's identity is a point of arrival (or stabilization), the product of all systemic affections. This idea we already find in Spinoza's Ethics, Proposition 6 of Part III of : "Every thing, as it is in itself, strives to persevere in its being".

This Spinozist definition of conatus lead us to the idea of a metastable system as the set of affections and affects (affectus) unfolding in a duration, so that identity (unity, the individual) can only be thought of as a byproduct of this tendency (conatus, desire). The person before us, the bunch impression defined as characteristics of a subjectivity (the ego, the self) thus depends on a set of affections (feelings and emotions).

The overlap between affection and affect, the true mechanism of emotions, can then be understood as the contraction/contemplation "reading" the modifications or the relationship between inner and outer consisting of a reactive sensorimotor system. This system has no command center being in fact an homeostatic regulation machine as remarked by Damasio:

\begin{abstract}
All living organisms from the humble amoeba to the human are born with devices designed to solve automatically, no proper reasoning required, the basic problems of life. Those problems are: finding sources of energy, incorporating and transforming energy; maintaining a chemical balance of the interior compatible with the life process; maintaining the organism's structure by repairing its wear and tear; and fending off external agents of disease and physical injury. The single word homeostasis is convenient shorthand for the ensemble of regulations and the resulting state of regulated life (DAMASIO, 2003, p. 30).
\end{abstract}

To better understand the idea of this true homeostatic mechanism we have to understand the meaning of the concepts of affection and affect. Spinoza defines affection and affect in the Preface of Book III of Ethics: 
3. By emotion (affectus) I understand the affections of the body by which the body's power of activity is increased or diminished, assisted or checked, together with the ideas of these affections (SPINOZA, 2002, p. 278).

This definition is complemented by two postulates:

1. The human body can be affected in many ways by which its power of activity is increased or diminished; and also in many other ways which neither increase nor diminish its power of activity [...]

2. The human body can undergo many changes and nevertheless retain impressions or traces of objects [...] and consequently the same images of things (SPINOZA, 2002, p. 278, 279)

There is therefore a subtle distinction between affection and affect, and Deleuze clarifies the meaning of these terms by stressing the importance of this distinction and its relation to the variations of power (or intensity) and its intrinsic duration:

[...] 1. The affections (affectio) are the modes themselves. The modes are the affections of substance or of its attributes (Ethics, I, 25, cor.; I, 30, dem.). These affections are necessarily active, since they are explained by the nature of God as adequate cause, and God cannot be acted upon.

2. At a second level, the affections designate that which happens to the mode, the modifications of the mode, the effects of other modes on it. These affections are therefore images or corporeal traces first of all (Ethics, II, post. 5; II, 17, schol.; III, post. 2); and their ideas involve both the nature of the affected body and that of the affecting external body (II, 16). "The affections of the human body whose ideas present external bodies as present in us, we shall call images of things ... And when the mind regards bodies in this way, we shall say that it imagines."

3. But these image affections or ideas form a certain state(constitutio) of the affected body and mind, which implies more or less perfection than the preceding state. Therefore, from one state to another, from one image or idea to another, there are transitions, passages that are experienced, durations through which we pass to a greater or a lesser perfection. Furthermore, these states, these affections, images or ideas are not separable from the duration that attaches them to the preceding state and makes them tend towards the next state. These continual durations or variations of perfection are called "affects," or feelings (affectus) (DELEUZE, 1988a, p. 48 and 49).

According to this perspective, the emotions' homeostatic system would be this "reading" of the duration of relations (encounters) of the organism with its own exteriority, that is, of the multiple relationships that affect and interfere, increasing or decreasing the range of action of a body.

Deleuze takes up this same distinction in his class on Spinoza on January 20, 1981, to emphasize that affections are the passage from one affection to another, or rather, the "reading", retention of increases and decreases in the power of acting (duration) (DELEUZE, 2011, p. 226-229). Thus, the affections are encounters between bodies and carry with them the image of these encounters. Encounters, in turn, involve variation, 
passage, or duration as the power of action increases or decreases. The greater the range of action, the greater the joy. On the contrary, the smaller the range of action, the greater the sadness.

Therefore, in a Spinosist sense, we could present the relations between bodies as a pure mechanism of affection. This mechanism is primarily corporeal and extends outside the organism, corresponding to a sensation or perception (passing from one state to another) that is independent of any "phenomenal property". Moreover, this mechanism precedes and is independent of any rationality.

Thus, the modulating mechanism in complex organisms is affective and involves the basic feelings of joy and sadness corresponding to the tendency of the organism ${ }^{4}$ (as both appetite and desire) "to persist in its own being [for an] indefinite time" (SPINOZA, 2002, p. 283). So the systems metastability drives the passage from affections to affections that, in turn, are intrinsic to any judgment (" [...] it is not because we judge a good thing that we strive because we want it, we want it, we want it, but on the contrary, it is because we strive for it, want it, feel it, want it, that we think it is good").

\section{Beyond Sadness}

With these introductory notions, we can approach theme itself: the zero degree of affect.

For Catherine Malabou (2012a, p. 8-10), philosophy has always had difficulty to think about metamorphosis. In its traditional mode, philosophy in multiple ways sought to stop motion and contemplate universe in its eternal and invariable form. On the contrary, it is common for poststructuralists to develop a new economy of these relations: movement is constitutive. However, even the philosophers who preceded her would have hesitated to

\footnotetext{
${ }^{4}$ In the Scholium of proposition 9 of Book III of Ethics we find a detail of the relation of this tendency to desire: When this conatus is related to the mind alone, it is called Will [voluntas]; when it is related to mind and body together, it is called Appetite [appetitus], which is therefore nothing else but man's essence, from the nature of which there necessarily follow those thing that tend to his preservation, and which man is thus determined to perform. Further, there is no difference between appetite and Desire [cupiditas] except that desire is usually related to men insofar as they are conscious of their appetite. Therefore, it can be defined as follows: desire is "appetite accompanied by the consciousness thereof."

It is clear from the above considerations that we do not endeavor, will, seek after or desire because we judge a thing to be good. On the contrary, we judge a thing to be good because we endeavor, will, seek after and desire it (SPINOZA, 2002, p. 284).
} 
carry out deterritorialization/deconstructive movement to the end that could face an absolute discontinuity with identity. In the form of life redeemed and inspired by Messianism, philosophy always promises a safe haven after identity drift movement, remaining traces to be harvested ahead (MALABOU, 2012a, p. 12).

Instead, Malabou (2012a, p. 1-2) proposes to consider the possibility of the emergence — in the face of a random accident — of a "new, unprecedented character" who "cohabitates with the old and ends up taking his place". In most of its uses, concept of plasticity is purely positive, designating balance between reception and attribution of form. However, there is also a plastic art of destruction and it also configures. "A broken face is still a face, a stump is a form, a traumatized psyche remains a psyche. Destruction has its sculptor chisels" (idem, p. 4). On the borderline between neurobiology, psychoanalysis and philosophy, it is in Alzheimer's patients that Malabou will find a new configuration of contemporary trauma exceeding those that Freud and Lacan theorized. Along with war traumatized, natural or political disasters victims, among others, patients would translate a desert coldness that is completely indifferent to any affection.

Spinoza himself, in a certain passage of Book IV of Ethics, would have recognized an integral transmutation of identity possibility when he tells a Spanish poet story who was stricken with an illness and, after healing, completely forgot about his tragedies and comedies, as well as his mother tongue — turning himself into a kind of "adult child". Poet in question, Malabou reveals, is Góngora, who lost his memory a year before his death in 1627. "It is one of the only allusions", she says, "present in a philosophical text, to a destructive metamorphosis of a being, from which a new, somewhat undead being is born. The body can die without being dead" (MALABOU, 2012a, p. 33-34).

Inspired by Antonio Damasio works, Malabou proposes to extrapolate the spinozist conatus - divided between joy and sadness — and to think of a state that exceeds these variations of potency.

In order to think, to want, to know, things must have a consistency, a weight, a value, otherwise emotional indifference annuls the relief, erases differences in perspective, levels everything. When reasoning is deprived of its critical power, its ability to discriminate and make a difference that proceeds from emotion and affect, then, as Damasio says, it becomes cold-blooded reasoning, and no longer reasons: "selective reduction in emotion is at least as prejudicial for rationality as excessive emotion" (MALABOU, 2012a, p. 22). 
Awareness and emotion are inseparable. High-level cognitive functions such as language, memory, and reason are dependent on the formation of what Damasio calls "proto-self". Once emotional brain is struck, however, psychic life does not simply disappear it remains alive in its destroyed form. Aphasias, absence seizures, epileptic seizures, among others, would be occasions when this disconnected form of emotions manifests itself. "Lesional plasticity thus reveals a strange sculptural power that produces form through the annihilation of form" (MALABOU, 2012b, p. 47-49). Citing some of the cases mentioned by Antonio Damasio, such as David and Phineas Gage, both with brain damage caused by accidents, philosopher seeks to think about how disaffection produces intellectual functions corrosion, establishing serious problems of cognition and judgment and creating kind of nihilism state of absolute indifference (idem, p. 49-53).

Still following Damasio, Malabou takes the "somatic markers" 5 perspective to think about their deactivation possibility, when those hit by emotional brain destruction become deserters below or beyond their own sadness or madness. As the philosopher states, "The patients Damasio mentions have not lost their reason strictly speaking. Usually, their intelligence is perfectly intact. But they have left reason, they have detached themselves from it, through their inability to be affected by it" (MALABOU, 2012a, p. 23).

In "The New Wounded", Malabou had explored this dimension of "cerebrality" that would form a domain not subsumed under the Real-Imaginary-Symbolic Lacanian scheme, constituting a dimension unmediated by the language that she calls "material". Material would "constitute the sense of an affective economy that solicits itself without seeing itself" (MALABOU, 2012b, p. 140). A kind of unconscious of psychoanalytic unconscious, cerebrality would be characterized by purely negative access, that is, it would only be self-affecting through its damage or interruption. Only through its destruction that it becomes visible (MALABOU, 2012b, p. 46).

Freud's death drive already established a return to the inorganic, a "conservatism" that repels vital tension. Understood as a kind of "impulse, inherent in organic life, to

\footnotetext{
${ }^{5}$ Somatic mark hypothesis involves emotion-based signals that allow separation between self and non-self. The "mind" construction for Damasio would be directly related to generation of these feelings, understanding the self as "dynamic collection of integrated neural processes, centered on the representation of the living body, that finds expression in a dynamic collection of integrated mental processes" (DAMASIO, 2010, p. 17), as we defined as a "reading" before.
} 
restore the former state of affairs," the drive would reveal that "the aim of all life is death" and that "inanimate things existed before the living" (FREUD, 1961, p. 30-33). Yet death drive would still retain an indestructible "primitive self", which would always refer to therapeutic hope of reparation by subjectivity and language, while destructive plasticity is beyond plasticity itself — in the positive sense that is usually given as creative recovery of neuronal connections. In destructive plasticity, death has already been accomplished by metamorphosis: there is a form of death during life marked by affective indifference (MALABOU, 2012b, p. 213-214).

Deleuze and Guattari write "The Anti-Oedipus" as a counterpoint to the psychoanalytic family novel dominated by the Oedipal form (DELEUZE \& GUATTARI, 1983, p. 51). Instead, they articulate intersections between psychic and somatic under a machinic regime in which everything is production. Then Freudian impulses that had given so much thought to Reich and Marcuse, for example, in the same period, simply disappear. Psychic is immersed into the social and, therefore, into the political and economic (idem, p. 95-106). In place of the theater of bourgeois representation, a semiotic factory that produces multiple forms of life (idem, p. 271). "Anti-Oedipus" seems to be the moment when drive for decoding, chaos defense as quintessential productive mode for a non-fascist life, ends up taking the stage. "Destroy, destroy. The task of schizoanalysis goes by way of destruction - a whole scouring of the unconscious, a complete curettage" (idem, p. 311). Or, "It should therefore be said that one can never go far enough in the direction of deterritorialization: you haven't seen anything yet — an irreversible process" (idem, p. 321).

In "A Thousand Plateaus: Capitalism and Schizophrenia", already without same enthusiasm with the winds of 68 , Deleuze and Guattari seems to review at various points the Dionysian experience they had worked on in the previous book. If, on the one hand, psychoanalysis says "'stop, find yourself again' we should say instead, 'Let's go further still, we haven't found our BwO yet, we haven't sufficiently dismantled our self", same passage warns that it takes not wisdom, but "as a rule immanent in experimentation: injections of caution" since "many have been defeated in this battle." Junkie body — which is among various examples exposed there — is passed by "refrigerator waves" that, instead of filling, empty the CsO (DELEUZE \& GUATTARI, 1987, p. 150-154). 
Psychoanalysis, while introducing that desire does not submit to procreation or even genitality, would still be hostage to the "ridiculous death instinct", clinging to ghosts and thereby despising "animal becoming" of the masochist (DELEUZE \& GUATTARI, 1987, p. 155). The $\mathrm{CsO}$ would be a field of immanence experience alien to norms that transcends their own plane of consistency. Its enemy is not the organs, but the organism as the "judgment of God," that is, sedimentation and stratification (idem, p. 158). However, disarticulating an organism is not an operation with hammer blows. Instead, it is "with a very thin file" that "self-destructions that are not confused with the death drive" are invented. Again, caution is required:

\begin{abstract}
You have to keep enough of the organism for it to reform each dawn; and you have to keep small supplies of significance and subjectification, if only to turn them against their own systems when the circumstances demand it, when things, persons, even situations, force you to; and you have to keep small rations of subjectivity in sufficient quantity to enable you to respond to the dominant reality. Mimic the strata. You don't reach the $\mathrm{BwO}$, and its plane of consistency, by wildly destratifying. [...] If you free it with too violent an action, if you blow apart the strata without taking precautions, then instead of drawing the plane you will be killed, plunged into a black hole, or even dragged toward catastrophe. Staying stratifiedorganized, signified, subjected - is not the worst that can happen; the worst that can happen is if you throw the strata into demented or suicidal collapse, which brings them back down on us heavier than ever (DELEUZE \& GUATTARI, 1987, p. 160-161).
\end{abstract}

As can be seen, it is precisely in this slide that Deleuze and Guattari want to avoid that Malabou thinks about the condition of contemporary disaffection from the braininjured paradigm. The black hole — which also later appears as the most dangerous deterritorialization movement in which war machine works only for its own war, plunging into pure destruction - is the experience of life under the rugged condition that Malabou recounts, in which coldness turns off somatic markers and renders affections neutral, producing a state of death in life.

\title{
4. Zero Degree Affects as an Horizon
}

What is the meaning of this state of death in life. It needs to be explained, of course. If not by a causal chain which, in turn, would inevitably refer to the cause of causes, at least by a principle of immanence.

This condition of neutrality must be understood as equivalence between what Spinoza calls attributes (extension and thought). Equivalence is not synonymous with 
parallelism. It expresses in fact the idea of the unity of attributes. There is necessarily a unity between body and mind. This unity or equality is the affective/cognitive life's background. Referring specifically to the Deleuzean reading, Chantal Jaquet enphasizes the relevance of this subtle distinction:

Despite his precautions and his mistrust of the term 'parallelism', Deleuze still resorts to this crutch that finally prevents him from focusing on the elucidation of the fundamental concept of equality, the importance of which he has nevertheless stressed. He states, in effect, that "it is the equivalence of attributes that gives parallelism its strict meaning, ensuring that the connection is the same between things whose order is the same." While recognizing that, unlike Leibniz, Spinoza does not use the word "parallelism," he argues that "this word suits his system because it equalizes the principles from which the independent and corresponding series derive." This word, sometimes becoming the asylum of ignorance, has eclipsed the word "equality," to which Spinoza expressly refers (JAQUET, 2011, p. 19).

Let us then see how this equivalence (equality) of attributes enables us to speculate about an affective zero degree which, in turn, would sometimes act as a "horizon," a phasic transition with no return. Let us also see how, from then on, we can think of a lower limit for affects (death, neutrality, relation without terms) in which the body (unrelated to any affection) is not affected, does not suffer any emotion or feeling. This limit, an unattainable regulatory ideal, will be useful to think destructive plasticity as affective emptiness.

We must warn, in advance: we are not advocating any kind of return of the Negative as supernatural exteriority: zero-degree is not the negation of affections, nor the non-affection. Rather, it is the gray zone where affections fluidize toward the undefined.

That said, equivalence of attributes attests the embodiment of trauma and the spiritualization of injury, since it operates from the perspective of a flat ontology (DELEUZE, 1988b, p. 124-131).

We can again turn to Deleuze when he reminds us of that great lesson from Spinoza: "No one knows what a body is capable of. "This statement, "No one knows what a body is capable of", implies (given the equivalence of attributes): "No one knows what consciousness is capable of". If there is a limit to the body, this limit is given in practice and only in practice. And only in experience can this limit be surpassed. A body is always subject to the experience of the event (the accident, the destruction coming from the outside). 
The same can be said of mind, consciousness, and cognition, according to the Deleuzean lesson: If no one knows what a body is capable of, it is also true that "no one knows what thought is capable of". If there is a 'gray zone', a distinct and obscure zone beyond the body, there is also an unconscious of thought, exteriority, indistinctness from where consciousness emerges ${ }^{6}$.

There is therefore this horizon, a sort of "groundless ground" as the unit of attributes, to which we must refer when we think of the "deactivation of the emotional brain."

So it is from Spinoza himself that we can think of this horizon, this affective zerodegree as a condition of possibility for joy, sadness and appetite or, if we wish, as a condition for the possibility of expression.

Becoming Another assumes here this dimension tied to a machine of forms of expression. It would be to say that destructive plasticity, as an event, is variation that distributes forms of expression. You do not form for yourself a Body Without Organs, you participate in a remitting event that forces openness to $\mathrm{CsO}$, which sets another tendency as conatus. As an event, destructive plasticity operates in the manner of chaotic attractors in dynamic systems: somatic markers forced to a phasic transition. A new self-regulatory tendency has its place. A new (self) perception emerges.

Destructive plasticity thus conceived is nonetheless this encounter between exteriority and interiority: an exterior event leading the metastable system to another level

\footnotetext{
${ }^{6}$ Deleuze himself remarks this unity: "The fact is that consciousness is by nature the locus of an illusion. Its nature is such that it registers effects, but it knows nothing of causes. The order of causes is defined by this: each body in extension, each idea or each mind in thought are constituted by the characteristic relations that subsume the parts of that body, the parts of that idea. When a body "encounters" another body, or an idea another idea, it happens that the two relations sometimes combine to form a more powerful whole, and sometimes one decomposes the other, destroying the cohesion of its parts. And this is what is prodigious in the body and the mind alike, these sets of living parts that enter into composition with and decompose one another according to complex laws. The order of causes is therefore an order of composition and decomposition of relations, which infinitely affects all of nature. But as conscious beings, we never apprehend anything but the effects of these compositions and decompositions: we experience joy when a body encounters ours and enters into composition with it, and sadness when, on the contrary, a body or an idea threaten our own coherence. We are in a condition such that we only take in "what happens" to our body, "what happens" to our mind, that is, the effect of a body on our body, the effect of an idea on our idea. But this is only our body in its own relation, and our mind in its own relation, and the other bodies and other minds or ideas in their respective relations, and the rules according to which all these relations compound with and decompose one another; we know nothing of all this in the given order of our knowledge and our consciousness. In short, the conditions under which we know things and are conscious of ourselves condemn us to have only inadequate ideas, ideas that are confused and mutilated, effects separated from their real causes (DELEUZE, 1988a, p. 19).
} 
- with no return - through the activation of chaotic attractors inside the homeostatic system. The plasticity as constitutive wound (not in the metaphorical sense), the wound that will accompany personality as a scar, as an indelible mark, as a sign of an exceed limit, as a sign of disaffection.

\section{Disaffection}

Disaffection is viewed as another real world. The affective emptying exists as an affective world (which has plasticity as a paradigm) becoming real. This affective has its priority to any reflection on symbolic relations. But not only that: it also attests that affects (and affections) are the constitutive limit of the tendencies of the lived. Once this limit is reached (disaffection), other affects (another conatus, tendency) takes place.

Hollywood offers us two examples of the disaffection as organic transition (new personality with unprecedented bodily and psychic attributes): Anakin Skywalker in Star Wars: Episode III — Revenge of the Sith (2005) and Alex Murphy in Robocop (1987). These two characters are examples of what, with Malabou, we have been calling destructive plasticity. In the first case, Anakin, after undergoing a near-death experience, mutilations and multiple injuries, emerges as Darth Vader leaving behind the aspiring Jedi personality. Something similar happens in the second case. Alex Murphy, a police officer from the Detroit Police Department, who is ambushed and brutally murdered. As his legal death is declared, Murphy becomes a new hybrid homeostatic system, emerging as Robocop.

As it is well known Hollywood needs to keep the coherence (organic and psychic) of the characters in both cases (otherwise it would not be Hollywood ...). Both Darth Vader and Robocop end up revisiting Anakin and Murphy respectively.

But this is not an important issue here. What matters is this event, the destructive plasticity: a persona (personality), struck from the outside, undergoes an affective emptying leading to a relentless homeostatic reconfiguration and giving rise to new affects, a new personality, a tendency or conatus reconfiguration. In both cases, it is pertinent to remember, what is at stake is the death drive, the disaffection going beyond a given threshold, which breaks the membrane that separates outer and inner giving rise to a new personality. Similarly, in both cases, destructive plasticity, with its disaffected bodies, has political contours. 


\section{Necropolitics of zero-degree affects}

Achille Mbembe in his reflections on necropolitics has highlighted the central role of the death drive as a vector that connects affect to a scenario in which death becomes fundamental principle of politics. Mbembe's work bears clear Lacanian resonances, bringing the French tradition of receiving the Hegelian master and slave dialectic into Kojève and Bataille and placing "risking life" as a central element in understanding the masterly position which, in turn, grounds racism as black's enslavement in Western politics. Thus, the surplus, Dionysian impulse that fosters Bataille's Nietzsche-Hegelian work is reinterpreted - or even reversed - as dominant, death drive that submits representations and ghosts of black bodies to white supremacy (MBEMBE, 2003).

Despite this psychoanalytic connection, one could speculate on what would mean an expansion of the necropolitical horizon beyond Lacanian enjoyment domain, filling instead with the disaffection of these undead elements that roam the figurations of destructive plasticity from Malabou. Mbembe himself approaches this exercise by drawing the figure of the lumpenradical, whose survival in an environment of extreme cruelty and violence would lead to a destructive and nihilistic impulse:

Tyranny taught him to speak a filthy language devoid of symbols, the language of these bodies and lives transformed into sewers. It has produced innumerable cracked characters, hundreds of thousands of failed lives whose unscrupulous political entrepreneurs consider themselves, at their own risk, the megaphones. These are lives now eaten away by boundless resentment, the thirst for revenge, the drunken attraction of a party, the carnage and the foolish violence to which, they believe, our destiny is called. This "lost generation" believes that the only thing left for us to do is to fight fire with fire, junk with garbage, violence with more violence, by turning the poison against those who have manufactured. (MBEMBE, 2017, our translation).

Emotional brain deactivation through violent shocks that injure psyche and produce indistinctness between social and biological propagates cold figures, unable both to share suffering or make an ethical judgment about action. Violence victims become its propagators. The return to this bottomless bottom, this unconscious (neuronal) of the unconscious (symbolic), produced by a wound, engenders a horizon in which death itself a kind of organism zombie state of affective indifference - is still lived, although one can scarcely find any quality in an existence whose relation to the world proceeds only in undifferentiated form. 
Disaffected bodies, struck by the traumatic violence that invades their own neuronal organization, take revenge in a context in which cruelty itself - which, good or bad, is a relationship to the body - is no longer possible. Desperation not to be affected becomes destructiveness. Destructive plasticity is a threat that erodes social life and as such endangers the organisms very existence it coldly seeks to destroy.

\section{References}

APEL, K.-O. Towards a Transformation of Philosophy. Michigan: Marquette University Press, 1980.

BRAVER, L. A Thing of this World: A History of Continental Anti-Realism. Evanston: Northwestern University Press, 2007.

BRYANT, L. et al. The Speculative Turn: continental materialism and realism. Melbourne: re.press, 2011.

DAMASIO, A. Y el cerebro creó el hombre. Trad. Ferran Orti. Madrid: Destino, 2010.

DAMASIO, A. Looking for Spinoza: Joy, Sorrow, and the Feeling Brain. London: William Heinemann, 2003.

DELEUZE, G. En Medio de Spinoza. 2ed. Buenos Aires: Cactus, 2011.

DELEUZE, G. Spinoza: Practical Philosophy. San Francisco. City Lights Books, 1988a.

DELEUZE, G. Foucault. Minneapolis. Minnesota University Press, 1988b.

DELEUZE, G.; GUATTARI, F. Anti-Oedipus. Trans. Robert Butley et al. Minneapolis. Minnesota University Press, 1983.

DELEUZE, G.; GUATTARI, F. A thousand plateaus. Trans. Brian Massumi. Minneapolis. Minnesota University Press, 1987.

SPINOZA, B. Complete Works. Indianapolis: Hackett Publishing Company, 2002.

FREUD, S. Beyond the pleasure principle. Transl. James Strachey. New York/London: W. Norton \& Company, 1961.

HÄGGLUND, M. Radical Atheism: Derrida and the time of life. Stanford: Stanford University Press, 2008.

JAQUET, C. A Unidade do Corpo e da Mente: Afetos, ações e paixões em Espinosa. São Paulo: Autêntica, 2011.

KIRBY, V. Tracing life: 'la vie la mort'. The new continental review, v. 9, n. 1, p. 107-126, 2009. 
MALABOU, C. Une seule vie. Résistance biologique, résistance politique. Esprit 2015/1 (Janvier), p. 30-40, 2015.

MALABOU, C. Ontology of the accident: an essay on destructive plasticity. Transl. Carolyn Shread. Cambridge: Polity, 2012a.

MALABOU, C. The New Wounded: from neurosis to brain damage. Trasl. Steven Miller. New York: Fordham University Press, 2012b.

MALABOU, C. Que faire de notre cerveau? Paris: Bayard Éditions, 2011.

MALABOU, C. Que faire de notre cerveau? Paris: Bayard Éditions, 2011.

MBEMBE, A. Necropolitics. Public Culture, v. 15, n. 1, p. 11-40, 2003.

MBEMBE, A. "Le lumpen-radicalisme et autres maladies de la tyrannie », Le Monde, 2017. Available at: <https://www.lemonde.fr/afrique/article/2017/12/28/le-lumpen-radicalisme-et-autresmaladies-de-la-tyrannie_5235406_3212.html>. Access in: 12 aug. 2019.

PROTEVI, J. Adding Deleuze to the mix. Phenomen Cogn Sci, v. 9, p. 417-436, 2010.

RORTY, R. Ensaios sobre Heidegger e Outros. Trad. Marco Antonio Casanova. Rio de Janeiro: Relume-Dumará, 2002.

VITALE, F. Biodeconstruction: Jacques Derrida and the life sciences. Trad. Mauro Senatore. New York: Suny Press, 2018. 